\title{
THE IMPACT OF AUTOMATION AND ROBOTICS ON MOTIVATION
}

\author{
Krecz, Péter - Herneczky, Andrea - Csernák, József - Baranyi, Aranka
}

\begin{abstract}
Special attention should be paid to the human factors that influence the competitiveness of companies when analysing the correlations of economic processes. It is no longer controversial today that human capital is an important and crucial factor in a company's performance. The efficient, effective contribution of buman resources to an organization's success depends to a large extent on how it can ensure employees' motivation in the long run. Robotics and automation are gaining more and more ground nowadays. In our study we explore how employee motivation is influenced by the rapid and widespread use of robotics. The industrial revolution that is still going on today is bringing enormous changes. The industrial revolutions that happened earlier in history have fundamentally changed the lives of people and have always posed serious challenges to various economic actors. Changes have had a dual impact in the past. On the one hand, industrial production has resulted in a change in the economy and, on the other hand, a buge change in the social structure. In recent years, mechanization has seemed extreme, but this phase must be seen today as a natural part of daily life.
\end{abstract}

Keywords: industrial revolution, buman resources, motivation, robots JEL: M41

\section{AZ AUTOMATIZÁCIÓ ÉS A ROBOTIKA MOTIVÁCIÓRA GYAKOROLT HATÁSAI}

\section{Összefoglalás}

A gazdasági folyamatok összefüggéseinek. vizsgálata során különös figyelmet érdemelnek azok a bumán tényezök, amelyek a szervežetek versenyképességének meghatározó tényezőii. Ma már nem megkérdöjelez̧hetó, hogy a humán töke, egy vállalkozás sikerességének nélkeülözhetetlen és kulcsfontosságú tényezöje. Az emberi eröforrás eredményes, batékony hozzájárulása a szervezet sikeréhez. nagymértékben függ attól, hogyan lehet hosszú távon biztositani a munkavállalók motivációját. Napjainkban egyre inkább teret nyer a robotika, automatizáció. Kutatásunkban azzal foglalkozunk, hogyan befolyásolja a robotizáció gyors és széleskörü térnyerése a munkavállalók motiváaióját. A napjainkban is zajló ipari forradalom jelentös változásokat hoz az életünk minden területén. A történelem során korábban lezajlott ipari forradalmak, gyökeresen változtatták. meg az emberek bétköznapjait, és mindig komoly kibivások elé állitották a különbözó gazdasági szereplöket. A múltban bekövetkęrett válto zásoknak kettós hatása volt. Az ipari termelés egyrészt a gazdaságban jelentett korszakváltást, másrész̨ jelentös társadalmi struktúraváltást eredményez̨ett. Az elmúlt századokban a gépesités drasztikusnak tünt, napjainkban viszont ežt a folyamatot már a bétköznapok természetes velejárójának. kell tekinteni.

Kulcsszavak: ipari forradalom, humáneröforrás, motiváció, robotok

JEL: M41 


\section{Introduction}

Based on the literature review, within the framework of an empirical research we analysed the personal relationship of labour market actors linked to robotics and automation. We also presented the latest influence of robotics on the motivation of employees as a result of analytical studies. It is already possible to observe some trends, but they can differ greatly from country to country and region to region. This provides us with an accurate and up-to-date image of what motivating opportunities or obstacles in relation to digitization may currently fagriexist in potential employees.

The results of the secondary research will be contrasted with the data from the primary research, demonstrating whether there are variations between global trends and the situation of the labour market in Hungary. We also examined whether there is a discrepancy between labour market trends and employee competences, and after drawing our conclusions, we also made recommendations related to the topic.

\section{Research hypotheses}

We already have a lot of expertise in the field of automation and robotics as well as employee motivation, with regard to the subject we have selected, but the comparative analysis of the two fields is still a novel feature. Regardless of how well-established the research already known is, due to the details of the topic, continuous and frequent research is needed as the obsolescence of the acquired knowledge in the field of automation and robotics is extremely fast.

We set up our study hypotheses based on the literature and our own experiences, which are as follows:

Hypothesis 1: Employees' relationship to automation depends on demographic features.

Hypothesis 2: Employees are knowledgeable about automation and robotics and are not afraid of robots' taking ground.

Hypothesis 3: Technological advances and Industry 4.0 greatly reduce employee positive motivation.

\section{Literature review}

The fundamental cornerstone of the success of an organization is the selection of the right workforce. We must not stop at selecting the most qualified ones, human capital must be used efficiently for the success of the organization, and its continuous improvement should also be considered as a strategic task. If the right person who uses their resources with the right experience and dedication to accomplish organizational objectives is not found, the rest of the resources of the company such as physical assets, financial assets, and intellectual capital are worth nothing.

Human capital is often referred to as the capital of knowledge or intellectual capital, suggesting the significant role of human thinking, knowledge, creativity and decisions in the lives of today's organizations. (Bakacsi, 2010) The field of management that deals with individuals as an important, strategic resource of the company is human resource management. It seeks to use human capital efficiently to achieve a high degree of organizational and individual objectives. Human resource management is a trend in management that replaces the former personnel management. After the trends of scientific management and then human relations, the human resource-based approach 
evolved. It sees those who work in the organization as a fundamental (strategically important) resource of the organization and not as one of the organization's production factors that can be permanently substituted. (Vida et al. 2020) (Beck, 2019) (Bakacsi, 2010) (Gyökér, 2001) The fundamental task of human resource management is not only to establish agreement and harmony between the employer and the employee. The human resource management challenge is to create a situation between the employee and the employment in which the skills of the employee can match the requirements of the employer. (Gyökér, 2001) (Karoliny, 2010) The model of Human Resource Management (HRM) illustrates clearly how different factors impact one another. Automation has little effect on occupations where human resources are an integral, vital part of the work, where it is not possible to replace physical contact. For example, nursing, elderly care, where personal presence plays a very decisive role in these occupations.

At the same time, efforts to build humanoid-looking robots with emotional intelligence are constant. In „smart” HR processes using modern technical knowledge, recruiting and selecting labour force will improve processes in many places and make procedures more cost-effective and fairer. State-of-the-art analytical methods can be used to evaluate job-specific data sets, such as data on successful applicants that can be compared with the database of 'current abilities' or by relying on data from the biographies of external candidates to identify the most competent candidates with the appropriate skills. The organization can get a clear picture of the potential applicant with the advent of digital technology through software that identifies facial gestures, facial expressions, intonation, and spoken words, removing subjective personal assessment. In the virtual world, potential employees can get hold of plenty of data and reports on all related HR components as career start-ups on smartphones, speeding up the hiring process and alleviating the frustrations of the initial period, which may stem from a lack of information. (KSH, 2018). These technological solutions save significant time not only for new entrants but also for support colleagues during the standard orientation period. (KSH, 2018) In short, tasks related to certain roles may disappear with the spread of digitalization, others may become more "tangible," objective, or even fairer with the advent of technology, enabling HRM specialists to concentrate on other fields, assuming higher value-added activities. (KSH, 2018) To what degree will the human capital management system later be influenced in industries where this kind of artificial intelligence can also be applied?

The global labour market is dramatically changing as a consequence of Industry 4.0. (Széles, 2012) Existing occupations can be fully transformed or disappear dramatically. The so-called classical futures research was established in the mid-1900s, distinguished by a limited professionalism. Representatives of different fields, scientists and experts have discussed the major issues of the future using experimental approaches to look for a possible and appropriate vision. (Nováky, 2007) Future research can now be seen as a science that can be placed under the term social sciences within social psychology but has an interdisciplinary character at the same time. The future cannot be considered stable, but as a constant variable when talking about the future. We may infer from this that not just one option should be considered for the future. Research recommendations, in a global line of thought, must be promoted in parallel with the natural environment, culture, economy and technological growth. It is important to use qualitative and quantitative methods in the course of study, where forecasts can be developed in accordance with multiple disciplines (Hezam et. al. 2017). It is also recommended that the management of companies take into account the ideas gained and identified in the course of future research, as the business may even obtain market advantages in conjunction with the usual approach. Not only does this knowledge shed light on the possibilities open to the business, but it is also possible to examine potential obstacles in more detail. It is also necessary to follow the results of future researchers because companies also need to adapt to changes as quickly and flexibly as possible in 
today's fast-paced world. For a competitive future, the spread of artificial intelligence is decisive. By definition, a robot is an electromechanical structure capable of performing different tasks based on pre-programming. It can be under human direct control, but it can also do its job on its own, under a computer's supervision. According to ISO 8373, an industrial robot is an "automatic controlled multi-purpose manipulator with at least three programmable axes of movement (degrees of freedom) for fixed or moving installations used in industrial automation applications". (Szabó, 2014)

There has been an increasing demand in recent years on the part of the industry for the use of machines and equipment that can be used to speed up and automate production, so that many, even complex tasks can be performed accurately and within a short time. To date, this demand permeates robotic technologies. The objective is to build universal robots that are more precise and faster than the previous models. (Nováky, 2012) The relationship between man and machine is crucial, as one should not assume at all that the other can be fully replaced. We can make our processes and work easier and more precise during automation, but there are still sub-areas where human work is indispensable, especially human knowledge.

\section{Material and methods}

The main research issue is how workers react to the rise of automation and robotics, and how human motivation can be influenced in the workplace by future automation processes. A quantitative primary analysis was conducted during our research work using a form filling application available from Google services. The relationship between the variables was mainly explored by cross-tabulation analysis $\left(\chi^{2}\right.$ test). Regarding the content of the primary research and the questionnaire, the sample, which consisted mainly of members of the Facebook social network, was centred on the vast majority of individuals who are users of social media. The research phase started on 29 August 2020 and ended on 29 September 2020. The questionnaire consisted of $19+$ 2 questions that took no longer than 5 minutes to complete. Just 126 individuals completed the questionnaire. Of the respondents, 83 were women and 42 men.

\section{Results}

Of the respondents, 19 live in county seats and 23 in towns, representing $33.60 \%$ of the respondents. 31 of them live in villages, which amounts to 24.80 percent. In the capital, 52 of the respondents live, which is 41.60 percent of all the respondents. The sample evolved as follows after aggregation by qualification: 60.80 percent of respondents had tertiary education, i.e., 76 individuals. While 49 of the participants have a secondary education, which amounts to 39.20 percent, 51.20 percent of respondents (64 individuals) speak at least one foreign language at an intermediate level; 37 individuals, i.e., 29.60 percent of questionnaire respondents, speak two or more foreign languages.

At an intermediate level 19.20 percent of respondents do not at all speak a foreign language. 40.00 percent of those surveyed and responded to the questionnaire were thinking about trying their luck abroad and leaving the country behind, and another 24.80 percent of all respondents would certainly like to be tested outside the country. 44 of them do not want to work abroad, which is 35.20 percent. Of the respondents, 79.20 percent ( 99 individuals) have a white-collar job, of which 75.75 percent (75 individuals) work in jobs with more than 50 co-workers. In companies 
that often hire less than 50 employees, only 14.40 percent of respondents (18 people) do manual labour. The questionnaire data available showed that 61.60 percent of respondents said they had a job they are qualified for. 38.40 percent of respondents do not work in a job according to their education.

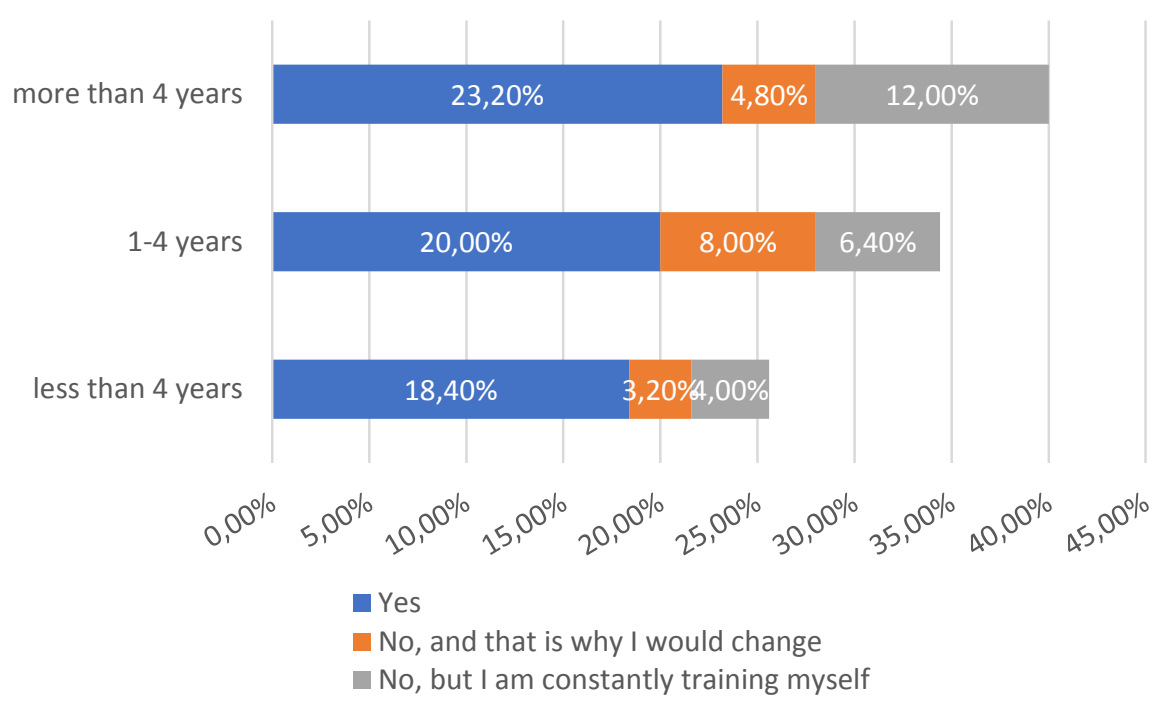

Figure 1 Time spent in a job for which the employee is qualified

There is no significant implication whether it can be said that with the rise in the number of jobs qualified for, the time spent at the same workplace would increase. (Figure 1) On the other hand, in the not-too-distant future, only 22.22 percent of respondents ( 28 people) could exclusively and primarily operate with robots, although 77.78 percent (98 people) are unable to consider this possibility. Even though two of the respondents are concerned, writing down and listing the following cases can still be worthwhile. When an employee also has ideas and is open to the subject, maybe they also have a full concept for implementation, sometimes the employer does not approve the idea. In these situations, the employee must decide whether the concept is really important and useful, which came from themselves, the employees. If so, but the idea has not yet been accepted at a given stage, it is worth maintaining the level of motivation for both parties by ensuring that the topic is not swept off the table by the employer, and the employee continues to work on it. Based on the available answers, the following rankings were made in terms of what they consider important at an ideal workplace. (Figure 2)

\section{Priority list at an ideal place of work}

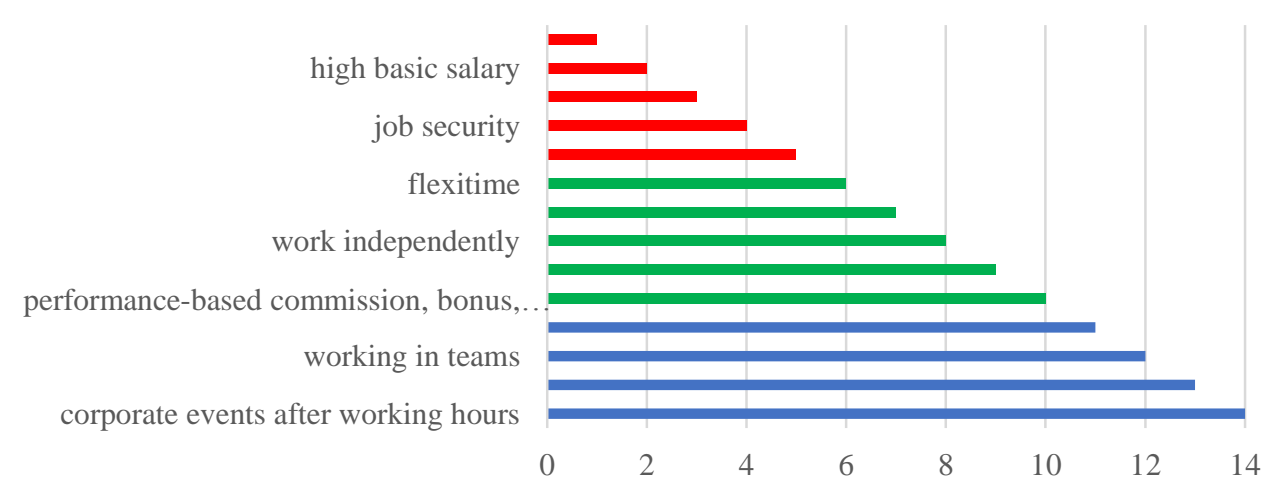

Figure 2 What do employees consider important at an ideal workplace? 
The Figure 3 provides the basis for the study of Yule's association coefficient, where we compared two quality criteria. Taking into account the related calculations, it can be stated that $\mathrm{a}_{\mathrm{y}}$ $=0.58$, according to which there is a rather weak relationship between the gender of the respondents and the nature of the work performed by them, where women do more intellectual work. In the present case, the first criterion attracts the first version of the second criterion.

\begin{tabular}{cc|cc}
\multicolumn{2}{c}{ The examination of association relationship } \\
& \multicolumn{3}{c}{ 2nd criterion } \\
& manual & intellectual \\
\hline \multirow{2}{*}{ 1st criterion } & male & 11 & 70 \\
& female & 7 & 29
\end{tabular}

Figure 3 Calculation of Yule's 2X2 variable association coefficient based on two quality criteria

In the following association examination (Figure 4), we sought to answer the question of what the relationship was between the gender of the workers and whether they could accept that they only had to work with machines. Based on this, the value of the Yule association coefficient is $\mathrm{a}_{\mathrm{y}}$ $=034$, according to which there is rather no relationship between the examined criteria, where both genders would rather not accept working only with machines later. In the present case, too, the first criterion attracts the first version of the second criterion. (Figure 4)

\begin{tabular}{cc|cc}
\multicolumn{3}{c}{ The examination of association relationship \#2 } \\
& \multicolumn{2}{c}{ 2nd criterion } \\
& accepting & $\begin{array}{c}\text { not } \\
\text { accepting }\end{array}$ \\
\hline \multirow{2}{*}{ 1st criterion } & male & 13 & 29 \\
& female & 15 & 68
\end{tabular}

Figure 4 Calculation of Yule's 2X2 variable association coefficient based on two quality criteria

The Figure 5 shows the respondents' qualification and how many foreign languages they speak at least at intermediate level.

\begin{tabular}{|c|c|c|c|c|c|c|c|c|c|}
\hline & \multicolumn{2}{|c|}{ Nome } & \multicolumn{2}{|c|}{1} & \multicolumn{2}{|r|}{2} & \multicolumn{2}{|c|}{3 or more } & \multirow{2}{*}{$\frac{\text { Total }}{\mathbf{N}}$} \\
\hline & $\mathbf{N}$ & $\%$ & $\mathbf{N}$ & $\%$ & $\mathbf{N}$ & $\%$ & $\mathbf{N}$ & $\%$ & \\
\hline $\begin{array}{l}\text { Secondary } \\
\text { education }\end{array}$ & 16 & $32,65 \%$ & 24 & $48,98 \%$ & 7 & $14,29 \%$ & 2 & $4,08 \%$ & 49 \\
\hline Tertiary education & 8 & $10,53 \%$ & 40 & $52,63 \%$ & 22 & $28,95 \%$ & 6 & $7,89 \%$ & 76 \\
\hline Total & 24 & $19,20 \%$ & 64 & $51,20 \%$ & 29 & $23,20 \%$ & 8 & $6,40 \%$ & 125 \\
\hline
\end{tabular}

Figure 5 Correlation between qualification and language knowledge

The cross-tabulation analysis showed that 4.08 percent ( 2 people) of those with secondary education $(\mathrm{N}=49)$ speak more than three foreign languages at least at intermediate level, while 14.29 percent (7 people) speak two, 48.98 percent (24 people) at least one language, and 32.65 percent $(\mathrm{N}=16)$ did not speak any language at the level mentioned. The proportion of those who speak several languages reaches thirty percent ( 28 people) of those with tertiary education $(\mathrm{N}=$ 76), whereas the proportion of the people who speak one language is 52.62 percent (40 people). 
The value of $p$ is 11 percent in connection with the correlation analysis above - where a significance level of 5 percent $(p=0.05)$ was identified in the Chi-square test. Based on this, it can be concluded that there is no significant relationship between education and language skills although the proportion of people who speak languages undoubtedly came from those with higher education.

The next analysis is centred on whether there was a connection between acceptance towards robots and generations. The answers showed that in the future, the vast majority of workers $(\mathrm{N}=$ 97) could not imagine having to deal exclusively with droids. In any case, it is important to note that the acceptance of robots in the direction of working with the possibilities of automation could only be noticed in the case of the new generation $\mathrm{Y}$ although this proportion is still very low. Incidentally, in terms of generations and accepting robots, no major correlation was found. In Question 16 of the questionnaire, I sought answers to the question in which sectors employees could imagine changes occur as a result of automation. On a scale from 1 to 5 , where $1=$ not at all and $5=$ absolutely, the answers to this question were collected. It is clear from the responses that they see the reality that automation can more drastically gain ground in the forthcoming period mostly in heavy industry and agriculture. In the Hungarian agriculture the small scale farms are in majority more than $40 \%$ of these farms are not profitable without subsidies (Sipiczki et al. 2019).Automation creates a competitive environment where the operation of these small scale farms is almost impossible. The lowest scores were given to healthcare and public administration. Respondents believe these are the two areas where they do not think robotics is gaining ground. The three hypotheses are partly built on top of each other or in parallel. It encompasses the point where the answer was sought to whether an employee has a characteristic that influences the relationship to automation, and whether knowledge or lack of it can cause resistance and fear. Furthermore, in the end, if certain changes have already taken place in relation to the topic, it is another question whether motivation is impaired or a different kind of new force is gained. The examinations can be interpreted separately, but the correlations and the logical relationship can be found between the hypotheses. The following figure illustrates that nearly 85 percent of today's workforce are familiar with and knowledgeable about automation and robotics, but the thing whether they are afraid of the changes that robotics can bring in the future is not so clear. After all, for this high level of knowledge, only 55 percent of respondents would not be afraid that robots could take the job away from humans. The cross-tabulation analysis reveals that there is a correlation between whether the employee is proficient in the topic of automation and whether they are afraid of the rise of robotics. The value of $\mathrm{p}$ is 0.007 (at a significance level of $5 \%$ ), and the Cramer index is $\mathrm{V}=0.312$, which means that the relationship can be considered moderately weak. It seems to be evident that employees who have learned, or are even part of such a process, that automation and robotics are gaining ground in the workplace are less scared that humans will lose their jobs to machines and robots. This evidence confirms the importance of the fact that education and training in a particular sector are also of great importance. After all, in the course of our work, our daily lives can be changed to a various extent by the new opportunities offered by technological development, and employees must be prepared for this.

In order to sustain and improve potential employee engagement, the fact that workers are always learning something new and have a vision and do not shy away from retraining opportunities plays an extremely important role. In light of this, it is essential for employers to recognize and try to communicate with their employees in light of this.

Performing value-added work based on the scale assessment obtained the highest score values. This could be the most significant motivating factor among the responding workers if changes were to take place in the future through the greater penetration of robotics, automation and digitization. 


\section{Summary}

\section{Hypothesis 1: Employees' relationship to automation depends on demographic features.}

It is obvious that various correlations between employees and automation can be observed for certain demographic features and attitudes. Intergenerational ties can be found, for example, and more and more knowledge collection through education, particularly language skills, affects the attitudes of employees and the acceptance of automation.

Hypothesis 2: Employees are knowledgeable about automation and robotics and are not afraid of robots' taking ground.

Employees have almost certainly learned and perceived that change has begun, and we are working at a rapid rate to ensure that robotics and automation are present in our work to the greatest extent possible. It also seems, though, that there is not yet a strong commitment in either direction to acceptance. Education and training must play an important role in changing the weight of the balance towards acceptance. In order to automate routine, manual operations, work automation also requires the implementation of technology. In addition to simplifying the workflow, monitoring parts of the process, and increasing overall efficiency, automation will encourage individuals to concentrate on a task based on expertise, enabling them to use their abilities more effectively.

In sectors such as manufacturing, where employees do strenuous job, work automation can be especially efficient. By performing repetitive tasks, machines may help support workers by reducing physical pressure and allowing employees to do more professional work.

Hypothesis 3: Technological advances and Industry 4.0 greatly reduce employee positive motivation.

It is an important HR task to ensure that workers in the company know exactly what automation at work means and why it will help both them and the business as a whole. In their own jobs, workers see retaining their motivation in their own work and are delighted to be part of retraining strategies. Employers must maintain this form of motivation and encourage employees to demonstrate in their job a motivated and value-creating mentality and attitude. In the new world created by the future, we see education as the key to making employment competitive and inspiring. It is important to anticipate the changes so that by the time a potential employee enters the labour market, they will already have knowledge of automation and, in addition to theoretical training, they should also have useful technical knowledge.

"In fact, a more beautiful and better future is approaching, we just need to see its beauty and understand where our place will be." (Beck, 2019: 14)

Artificial mechanisms free us from strenuous, demanding work.

\section{References}

[1.] Bakacsi Gy. (2010): A szervezeti magatartás alapjai. Budapest: Aula Kiadó.

[2.] Beck Zs. (2019): Válság vagy forradalom. Budapest: Beck and Partners.

[3.] Gyökér I. (2001): Humáneróforrás menedəssment. Budapest: Budapesti Mûszaki és Gazdaságtudományi Egyetem.

[4.] Hezam L. M. - Pataki L. - Tóth R. J.(2017): A humán tőke szerepe a vállalati életciklus szakaszok tükrében, Magyarország vidéki térségeiben. Pro Sciencia Ruralis, 2(1), 48-67. 
[5.] HRMS (HR and Payroll) (2018): Artificial Intelligence (AI): Smart Human Resource Management. SolutionDot. Accessed: 28 August 2020. URL: https://solutiondots.com/blog/hrms-hrpayroll/artificial-intelligence-ai-smart-human-resource-management

[6.] Karoliny M. - Poor J. (2010): Emberi eröforrás menedzsment kéziłkönyv. Budapest, CompLex Kiadó Kft.

[7.] Központi Statisztikai Hivatal (2018) Digitális gazdaság és társadalom. Budapest: KSH. Accessed: 03 September 2020. URL: https://www.ksh.hu/docs/hun/xftp/idoszaki/ikt/ikt18.pdf

[8.] Nováky E. - Hideg E. - Alács P. - Veigl H.(2012): Jövőkutatás - interaktivan. Budapest, Aula Kiadó.

[9.] Sipiczki, Z. - Bareith, T. - Varga, J. (2019): A magyarországi agrárszektor egyéni gazdaságai jövedelmezőségének alakulása 2013 és 2015 között. Statisztikai Szemle, 97(1), 72-89. DOI: 10.20311/stat2019.1.hu0072

[10.] Széles Zs. (2012): Development opportunities in information technology for Hungarian Agricultural Enterprises. Annals of the Polish Association of Agricultural and Agribusiness Economists, 14(1), 252-256.

[11.] Vida I. - Spaller E. - Vasa L. (2020): Potential effects of finance 4.0 on the employment in East Africa. Economy and Sociology / Economie si Sociologie, 2020 (2), 29-42. DOI: $10.36004 /$ nier.es.2020.2.03

\section{Authors}

Krecz, Péter

student

Magyar Agrár- és Élettudományi Egyetem

peter.krecz85@gmail.com

Herneczky, Andrea

$\mathrm{PhD}$

college associate professor

Magyar Agrár- és Élettudományi Egyetem

herneczky.andrea@uni-mate.hu

Csernák, József

ORCID: 0000-0002-9094-4384

$\mathrm{PhD}$

senior lecturer

Magyar Agrár- és Élettudományi Egyetem

csernak.jozsef@uni-mate.hu

Baranyi, Aranka

$\mathrm{PhD}$

associate professor

Magyar Agrár- és Élettudományi Egyetem

baranyi.aranka@uni-mate.hu 